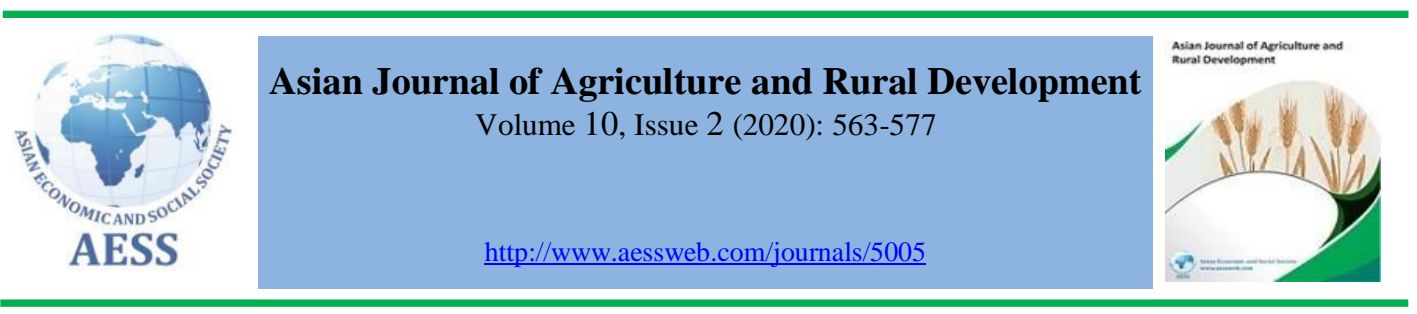

\title{
REGULATORY IMPACT ANALYSIS ROLES FOR AGRICULTURAL PRODUCTS' QUALITIES: CUSTOMERS' PERSPECTIVES FOR SUSTAINABILITY ENTREPRENEURSHIP
}

\author{
Zulhamri Abdullah ${ }^{\mathrm{a}}$, Communication Department, FBMK, Universiti Putra Malaysia, \\ Wan Fauziah Wan Malaysia \\ Yusoff ${ }^{\mathbf{b}}$, $\quad \quad{ }^{\mathrm{b}}$ Faculty of Technology Management \& Business, Universiti Tun \\ Chinedu Eugenia Hussein Onn, Malaysia \\ Anumudua, $\quad{ }^{\mathrm{c}}$ Faculty of Economics \& Management Sciences, Universiti Sultan Zainal \\ Fakhrul Anwar Abidin, Malaysia
}

Zainol $^{\mathrm{c}}$

\zulhamri@upm.edu.my (Corresponding author)

\section{ARTICLE HISTORY: \\ Received: $19-\mathrm{Feb}-2020$ \\ Accepted: 06-Apr-2020 \\ Online Available: 18-July- 2020}

\section{Keywords:}

Regulatory impact analysis, Agro-entrepreneurship, consumer-oriented, Asian country

ABSTRACT
The purpose of this study is to contribute to the emerging agro-
entrepreneurship empirical literature from the Malaysian regulatory
impact analysis context. Therefore, this study explicitly provides an
empirical analysis of the regulatory impact assessment based on
consumers' perceptions. In line with the purpose of the study, we
applied a quantitative approach through a survey questionnaire for the
aim of generating data from the central, south, and east coast Malaysian
consumers' opinions. Consequently, we found that the majority of the
respondents had little knowledge of the impact of grading, packaging,
and labelling (GPL). Furthermore, the study established that over two-
thirds of the customers always check the label of the products they
intend to purchase. The majority of the consumers were also concerned
with the Halal label when purchasing products.

Contribution/ Originality

The study contributed empirical evidence to the emerging agro entrepreneurship literature from the Malaysian improved regulatory impact analysis context.

DOI: 10.18488/journal.ajard.2020.102.563.577

ISSN(P): 2304-1455/ ISSN(E): 2224-4433

How to cite: Zulhamri Abdullah, Wan Fauziah Wan Yusoff, Chinedu Eugenia Anumudu, and Fakhrul Anwar Zainol (2020). Regulatory impact analysis roles for agricultural products' qualities: Customers' perspectives for sustainability entrepreneurship. Asian Journal of Agriculture and Rural Development, 10(2), 563-577.

(c) 2020 Asian Economic and Social Society. All rights reserved. 


\section{INTRODUCTION}

There is a notable lack of empirical research on whether regulatory impact analysis (RIA) might help in promoting agro-based products' qualities and sustainable agricultural entrepreneurship. The empirical gap was noticed from previous studies that have researched the factors influencing the growth of agro products and entrepreneurship stabilities (Ekpe et al., 2015, Haider et al., 2020; Zhang and Tidgren, 2018; Nie, 2020). Therefore, this research aims to empirically examine the roles of regulatory impact analysis on the Malaysian emerging agro entrepreneurs towards improving agricultural products' qualities from the customers' perspectives.

It is unarguably that every nation needs agricultural products to sustain its citizens. This is because the agricultural profession is deemed as one of the sectors that can bring about economic growth through generating incomes, food supply, raw materials, and providing employment opportunities, especially among the rural dwellers (Haider et al., 2020; Schneider et al., 2011). It also helps in attracting landscape transformations, societal developments, and ecocentric inventions needed in rural settings for sustaining socio-ecological environments towards promoting better rural livelihoods (Oliveira and Penha, 2020). Therefore, there are growing needs to regulate the qualities of agro-based products provide by agricultural entrepreneurs to the consumers to sustain the business at large. This is necessitated for gaining ground in the competitive markets (Bonroy and Constantatos, 2015) and also for promoting Eco-system-based adaptation practices (Vignola et al., 2015). However, agrobased entrepreneurs should endeavour to adjust their marketing strategies through improvising the qualities of agricultural products to sustain effective business practices to avoid creating unhealthy environments that may lead to artificial scarcity and unduly rivalries (Nie et al., 2020; Bowen et al., 2020; Zhang and Tidgren, 2018). This is because artificial scarcities of agricultural products might have vast effects on the consumers and agricultural products' suppliers by creating an unfair scenario for exploiting them. Artificial scarcity of agricultural products may also bring about higher prices that may lead to a decrease in demand, limitation on consumers' choices, economic inefficiency, mismanagement of resources, lack of corporate identity (Abdullah and Abu Seman, 2018) and loss of brand reputation (Abdullah, 2009).

To maintain quality and prevent unhealthy agricultural products' artificial scarcities; and competitions, previous related studies have shown that adopting standard policy and regulating body are indispensable for achieving stable and quality agricultural products (Kowalczyk et al., 2019; Zhang and Tidgren, 2018). Consequently, adopting standard policy and regulating impact analysis might improve the entrepreneurship developments in Malaysia (Ekpe et al., 2015; Ekpe et al., 2016). Presently, horizontal restraints on competition allow other competitors in the market, whereas vertical restraints promote supplier-distributor relationships (Nie et al., 2020). Nonetheless, it should be noted that the distinction between horizontal and vertical restraints on competition is not always a clear cut and practices because one type may impact the other. For example, firms may adopt strategic behavior to foreclose competition. They may do so by pre-empting facilities through acquisition of important raw material supply or distribution channels may enter into long term contracts to purchase available inputs or capacity and engage in exclusive dealing and other practices. These practices may raise barriers to entry and entrench the market position of existing firms and/or facilitate anti-competitive arrangements (Schneider et al., 2011).

Globally, most countries and governments, including Malaysia, face increasing challenges for designing regulatory systems that promote and protect the welfare of citizens (Abdullah, 2010) and to encourage corporate engagement with a larger community (Abdullah et al., 2017). Partly, this challenge could be resolved by integrating evidence basis in agricultural industry regulatory decision making. This is necessitated to ensure and improve agricultural products by implementing effective regulations for agro-based products. Regulatory Impact Analysis (RIA) is a method for assessing both the positive and negative effects of existing and proposed regulatory changes by the government at all levels in the agricultural industry, mainly within the Central government (Kirkpatrick and Parker, 2003; Parker, 2006). According to OECD (2020), RIA aims to be a tool and a decision process 
for informing political decision-makers to assess the predicted impacts (a so-called ex-ante assessment) or after a regulation has been implemented to see if the effects equate with those expected when the law was introduced (an ex-post assessment) in the agricultural industry. The beginning of the evaluation of Regulatory Impact Assessment (RIA) is the net benefits (or costs) that may result from state regulation. Therefore, RIA first formally surfaced as a process within the government in the USA in the 1970s, under the Nixon administration when US companies began to complain about costs of mainly environmental regulation. RIA has achieved wider popularity after the OECD started to champion the idea and published it in March 1995 (Kirkpatrick et al., 2003; Kirkpatrick and Lee, 2002).

OECD spearheaded the analysis scheme until it was officially renamed Regulatory Impact Analysis or Assessment in 1997. It equally released the first summary of best practices in RIA in the same year where it defined what RIA is, and also stated the main objectives and summarized what each country had achieved and what the results had been. The information was first acquired in the form of consultations. In 2005, the OECD published Guiding Principles for Regulatory Quality and Performance, which was another brief document for policy-makers of its members. Subsequently, in 2009, they released a whole book on the topic which presents alleged determinants of quality of RIA, suitable methodological frameworks to use and also chapters on how to integrate competition analysis into RIA and ideas on how to apply RIA in the area of corporate governance (OECD, 2020).

Presently, the impact of policy regulatory bodies in ensuring agricultural product qualities and sustaining agricultural smallholders are globally gaining ground even among European continents. Thus, a recent European study has found that such bodies play crucial roles in providing information and implementing laws that would trigger stakeholders, sciences, and citizens to quickly adapt to better strategies towards improving agricultural products' qualities. An example of such effective policy was seen from improvising agricultural water production quality through effective long-terms communication streams (Glavan et al., 2019). Similarly, a study conducted in Italy by Capone et al. (2016), which focused on developing methodological approaches for assessing agricultural products' qualities for better environments, economics, social, cultural, nutritional and Mediterranean Apulian agro-products consumers' sustainable health, demonstrated that implementing a viability logo could bring about effective promotion for rural agricultural productions and qualities. However, Pölling et al. (2017) proposed that policy assessments for improving agro-products' qualities and sustainable agricultural entrepreneurship could be influenced by the farmers' contextual regions. Consequently, the scholars' comparative studies in Spain, Italy, and Germany showed that integrating agricultural diversifications was the most business model that propelled agro-products' sustainability in these selected regions. Congruently, $\mathrm{Yu}$ (2017) claimed that economic rationale adopted by various regions determined the regulatory impact on agricultural products and economical growths. Therefore, the scholar illustrated that considering various external, internal, and autonomous factors while initiating regulatory impact analysis is capable of generating optimal income towards sustaining healthier business and economic modeling.

The integration of multiple regulatory management firms has also been suggested as a possible factor that might bring out enrichment to agro products' qualities and sustainable entrepreneurship (Akhmetova et al., 2019). The scholars experimented this by integrating quality management body and Hazard Analysis and Critical Control points towards improving the qualities of dairy products and found the combination successful for sustaining agro-products' potentials. Williams (2015) further argued that for large-scale agricultural reserves to progress, accumulated knowledge from agricultural related-investments needs to be considered. The scholar demonstrated this by experimenting with food and water securities in the Middle East and North Africa region and subSaharan Africa and concluded by illustrating that a combination of ecosystem management applications and smallholders are needed for intensifying and promoting agricultural products for better rural sustenance. Similarly, recent research by Paraskevopoulou et al. (2020) observed that agro-products' qualities are being globally confronted by sustainability issues and therefore calls for intensifying and fostering sustainable approaches via evaluating social and state economic existing rules towards obtaining useful information for improving and sustaining agro products. 
Recent research also emphasized that having regulating assessment bodies such as Alternative Food Network helps in analyzing and promoting agro-products' qualities. This was demonstrated by creating common networking sites where farmers will always project quality productions and the consumers' willingness to patronize such products provided they are eco-friendly ones (Corsi and Mazzocchi, 2019). Other groups of researchers propagated that integrating quality management systems will enable various enterprises to enhance striving towards meeting up with modern days' market necessities and also embrace healthy rivalries for better productions (Akhmetova et al., 2017). Regulating agro-products qualities has been also deemed essential among rural dwellers, especially in providing food safety information to them through designated quality products' firms since research has established that rural dwellers consumers' choices of locally agro products are influenced by the intention of improving social and economic growths in the rural settings instead of being influenced by civic conventions that promote products' qualities (Migliore et al., 2017).

Research further showed that agricultural products' quality promotions were not limited to only botany and subsistence farming but also needed in other branches such as aquaculture to enable adaption in the competitive markets (Neto et al., 2015). This is because every agricultural branch needs to embrace quality features to excel. Therefore, the roles of regulating and legalizing agro products are needed towards promoting agro-products' qualities and sustaining entrepreneurship in all agricultural branches. The adoption of Index insurance was identified as another way of sustaining smallholders. This might help and limit the obstacles that could be caused by imposing unapproved insurance coverage on them. Therefore, research suggested that establishing appropriate fixed metrics will help to enhance agro-products' qualities, consumers' protections, and controlling of unduly exploitations (Jensen and Barrett, 2017).

However, Abid et al. (2016) argued that the qualities of agro products, local food securities, and sustainability of agricultural entrepreneurship could be achieved by educating the farmers, providing them with easy access to farming consultation related-services, and by offering them information on the latest adaptation approaches. In contrast, Quintas et al. (2016) posited that introducing numerous ecosystem management approaches and inclusion of ecosystem in the land management could improve subsistence farming and promote agricultural smallholders' sustainability.

Therefore, in line with the uncertainties about not yet entirely ascertained the roles of Regulatory Impact Analysis (RIA) towards improving agricultural products' qualities and sustainable agrobased entrepreneurship in Malaysia as previous studies established, the study was guided by the following research questions and objectives:

\subsection{Research questions and objectives}

Research questions:

1) What is the current status of RIA within the agricultural industry in Malaysia?

2) How does RIA affect the agricultural industry in Malaysia?

3) What would be the mechanism to ensure the success of RIA for all stakeholders within the agricultural industry in Malaysia?

Research objectives:

1) To identify the current status of RIA within the agricultural industry in Malaysia.

2) To examine the impacts of RIA in the agricultural industry in Malaysia. 
3) To propose strategy or tools such as structure remedies in assisting the economy to enhance the agricultural industry in Malaysia

\section{METHODS}

The study employed a survey questionnaire approach for obtaining the perceptions of consumers from the central, south, and east coast of Malaysia. The developed instrument was validated by ascertaining their reliabilities and validities. The study covered a sample of vegetables and fruits consumers in Selangor and Johor. These two states were selected because they were the predominant agricultural zones that practice RIA in Malaysia. For this study, a total number of 800 questionnaires were distributed to selected respondents in Selangor (400) and Johor (400), respectively. The total recovered and filled questionnaire used for the study was 559 (70\%). This implied that $265(66.3 \%)$ of the questionnaires were recovered in Selangor.

While 294 (73.5\%) was retrieved from Johor respondents. In terms of sampling technique, simple random sampling was applied in both states. It was used because it offered everyone in the targeted population equal opportunity of being selected. Subsequently, the statistical package for the social sciences (SPSS) version 14 software was used to analyze the data. First of all, it is important to note that the research objectives determine the type of statistical tools that should be employed during the analysis stage. Therefore, the research objectives, which were: to identify the current status of RIA within the agricultural industry in Malaysia; examining the impacts of RIA in the agricultural industry in Malaysia and proposing strategy or tools such as structure remedies in assisting the economy to enhance the agricultural industry in Malaysia were all descriptive objectives. Consequently, descriptive statistical tools were used and analyzed the data, and these comprised measures of central tendency such as mean, percentage, and frequency, etc. They were applied because descriptive statistics were deemed appropriate for any quantitative descriptive studies (Carroll et al., 2017; Cooper et al., 2019). In other words, none of the objectives required inferential statistics such as ANOVA, Correlational effects, etc., because the objectives of the research did not have any needs for the inferential test. Therefore, descriptive statistical tools, which comprised frequency and percentage, were explicitly used and analyzed the data.

\section{RESULTS AND DISCUSSIONS}

This section described the socio-economic background of the consumers and subsequent findings of the study. According to Table 1 on the socio-economic background of the respondents, it presented that $54 \%$ of the respondents in the Selangor state were male while the rest were female. In other words, more than half of the respondents that participated in the study in the Selangor state were male. Whereas in the Johor state, it indicated that $69 \%$, which comprised the majority of the respondents were also male while the rest were female. This explicitly implies that the majority of the customers that patronize vegetables and fruits sellers in Selangor and Johor are the male consumers.

In terms of the consumers' level of education, more than one-third of the respondents in both Selangor and Johor had SPM/MCE, which stands for "Sijil Pelajaran Malaysia" this is previously known as the Malaysian Certificate of Education (MCE), and it is the official national examination taken by all Malaysian fifth form students. In contrast, the rest are having an STPM/Diploma, Bachelor's, Masters, and Ph.D. degrees. In other words, it pinpoints that SPM/MCE holders are patronizing fruit and vegetable sellers in both Selangor and Johor more than other levels of education.

Regarding the consumers' marital status, Table 1 illustrated that the majority of the customers who buy vegetables and fruits in the two states were married people. Conversely, married people are making more use of vegetables and fruits. Probably, it is because they have more family members who consume horticultural products than single and widowed ones. 
Pertaining to the race the consumers belonged, Table 1 demonstrated that the majority of the consumers in both Selangor and Johor states were from the Malay race. This was followed by Indian, Chinese, and others. Thus, it implied that the Malay race patronizes vegetable and fruit sellers in the two states more than other races.

Furthermore, it showed that the age of most of the consumers in both states was between 41-50 years; those between 21-30 years followed this. And it implies that the two age brackets mostly consume vegetables and fruits in the two states.

In terms of occupation of the consumers, the Table 1 displayed that the majority of the consumers in both Selangor and Johor are working in private sectors, and this was followed by sole traders. Therefore, private sector workers patronize vegetables and fruits sellers in the two states more than other occupations.

Finally, Table 1 showed that most of the consumers are monthly earning a household income of 234.87-703.90 USD, and this implies that most of the customers who patronize vegetables and fruits sellers in Selangor and Johor states are below Malaysia average income earners. It also corresponds with the consumers' level of education, which states that a greater percentage of them are having SPM/MCE, the second-lowest level of education in Malaysia.

Table 1: Descriptive outcomes of vegetable and fruit consumers' socio-economic background

\begin{tabular}{|c|c|c|c|c|}
\hline & $\begin{array}{l}\text { Selangor } \\
\text { Frequency }\end{array}$ & $(\%)$ & $\begin{array}{c}\text { Johor } \\
\text { Frequency }\end{array}$ & $(\%)$ \\
\hline \multicolumn{5}{|l|}{ Gender } \\
\hline Male & 143 & 54 & 203 & 69 \\
\hline Female & 122 & 59 & 91 & 31 \\
\hline Total & 265 & 100 & 294 & 100 \\
\hline \multicolumn{5}{|l|}{ Level of Education } \\
\hline UPSR and below & 8 & 3 & 12 & 4.1 \\
\hline PMR & 14 & 5.3 & 30 & 10.2 \\
\hline SPM/MCE & 97 & 36.6 & 107 & 36.5 \\
\hline STPM/Diploma & 62 & 23.4 & 59 & 20.1 \\
\hline Degree & 60 & 22.6 & 68 & 23 \\
\hline Master/PhD & 23 & 8.7 & 17 & 5.8 \\
\hline Others & 1 & 0.4 & 1 & 0.3 \\
\hline Total & 265 & 100 & 294 & 100 \\
\hline \multicolumn{5}{|l|}{ Marital Status } \\
\hline Single & 48 & 18.1 & 8 & 27.6 \\
\hline Married & 213 & 80.4 & 204 & 69.4 \\
\hline Widowed & 4 & 1.5 & 9 & 3 \\
\hline Total & 265 & 100 & 294 & 100 \\
\hline \multicolumn{5}{|l|}{ Race } \\
\hline Malay & 223 & 84.2 & 219 & 74.5 \\
\hline Chinese & 8 & 3 & 39 & 13.3 \\
\hline Indian & 26 & 9.8 & 22 & 7.5 \\
\hline Others & 8 & 3 & 14 & 4.7 \\
\hline Total & 265 & 100 & 294 & 100 \\
\hline \multicolumn{5}{|l|}{ Age } \\
\hline 20 Years Below & 4 & 1.5 & 6 & 2 \\
\hline 21-30 Years & 72 & 26.9 & 66 & 22.4 \\
\hline $31-40$ Years & 59 & 22.3 & 78 & 26.5 \\
\hline 41-50 Years & 62 & 23.5 & 75 & 25.6 \\
\hline
\end{tabular}




\begin{tabular}{lcccc}
\hline 51-60 Years & 53 & 20.1 & 52 & 17.7 \\
61 Years Above & 15 & 5.7 & 17 & 5.8 \\
Total & 265 & 100 & 294 & 100 \\
Occupation & & & & \\
Government & 55 & 20.9 & 46 & 15.6 \\
Business Owner & 58 & 22.1 & 73 & 24.8 \\
Private sector & 84 & 31.9 & 123 & 51.8 \\
Professional & 7 & 2.3 & 16 & 12.3 \\
Others & 61 & 22.8 & 36 & 100 \\
Total & 265 & 100 & 294 & 3.1 \\
Income (USD) & & & & 53.1 \\
Below 234 & 32 & 12 & 9 & 22.4 \\
$234.87-703.90$ & 104 & 39.2 & 156 & 4.8 \\
$704.13-1,173.02$ & 64 & 24.2 & 66 & 11.2 \\
$1,173.26-1,642.23$ & 14 & 5.3 & 14 & 5.4 \\
$1,642.46-2,346.94$ & 31 & 11 & 33 & 100 \\
Above $2,346.04$ & 20 & 7 & 16 & 294 \\
Total & 265 & 100 & & \\
\hline
\end{tabular}

\subsection{Grading, packaging and labeling (GPL)}

Regarding knowledge about GPL, Table 2 indicated that most of the vegetables and fruits customers in Selangor and Johor did not know about grading, packing, and labelling of agro- products' regulations. Therefore, it implies that they might have been buying goods that were not deemed safe for consumption since the aim of GLP is to ensure that products are graded, packaged, and labelled for safe consumption. In contrast, the least of them did not answer this particular question. It was also an indication that they were unaware of the GPL role in ensuring products' qualities. Thus, there is a need for GPL corporate firms to sensitize people on the impact of evaluating products' qualities through grading, packaging, and labelling. The enlightenment could be done through organizing GPL awareness campaigns or via various social media, especially the commonest ones such as Facebook and Whatsapp.

Table 2: Descriptive outcomes of vegetable and fruit customers' knowledge about grading, packaging and labelling (GPL) agro-products' regulation

\begin{tabular}{lcccc}
\hline GPL & $\begin{array}{c}\text { Selangor } \\
\text { Percentage (\%) }\end{array}$ & Frequency & $\begin{array}{c}\text { Johor } \\
\text { Percentage (\%) }\end{array}$ & Frequency \\
\hline Yes & 38.1 & 101 & 42.9 & 126 \\
No & 60.4 & 160 & 53.1 & 156 \\
N/A & 1.5 & 4 & 4.0 & 12 \\
Total & 100 & 265 & 100 & 294 \\
\hline
\end{tabular}

Similarly, Table 3 presented that most of the vegetable and fruit consumers in both Selangor and Johor did not answer this particular question, which focused on ascertaining if they purchase edible products based on the GPL stipulated rules. Therefore, this might be because they did not understand the concept of GPL rules on consumable products. Thus, it is suggested that the government or the body in charge of GPL should intensify their efforts towards enlightening the public on GPL rules for adequate evaluating the safety of the products they intend to purchase in the subsequent time. 
Table 3: Descriptive outcomes of the vegetable and fruit customers on purchasing agro products based on GPL rules

\begin{tabular}{lcccc}
\hline \multirow{2}{*}{ GPL rules } & \multicolumn{2}{c}{ Selangor } & \multicolumn{2}{c}{ Johor } \\
& Percentage $(\boldsymbol{\%})$ & Frequency & Percentage $(\boldsymbol{\%})$ & Frequency \\
\hline Yes & 21.9 & 58 & 9.9 & 29 \\
No & 18.1 & 48 & 18.0 & 53 \\
N/A & 60.0 & 159 & 72.1 & 212 \\
Total & 100 & 265 & 100 & 294 \\
\hline
\end{tabular}

Table 4 showed that the majority of vegetable and fruit consumers in both Selangor and Johor attested checking of products' labels before making payments. Thus, it is a commendable act since it would partly help them in verifying the products' consumption safety and qualities. It also implies that most of the customers are fully practicing the label checking part of GPL rules. However, there should be widespread concern about a few of them that have not started checking products' labels nor the concept behind doing so before making payments. Therefore, it is suggested that the few customers who don't check products' labels nor understand the impact of checking the labels should be updated about it through enlightening them on the need to do so in subsequent time.

Table 4: Descriptive outcomes of the vegetable and fruit customers about checking label before purchasing agro products

\begin{tabular}{lcccc}
\hline \multirow{2}{*}{ Label } & \multicolumn{2}{c}{ Selangor } & \multicolumn{2}{c}{ Johor } \\
& Percentage $(\boldsymbol{\%})$ & Frequency & Percentage (\%) & Frequency \\
\hline Yes & 78.5 & 208 & 78.2 & 230 \\
No & 20.8 & 55 & 19.7 & 58 \\
N/A & 0.8 & 2 & 2.0 & 6 \\
Total & 100 & 265 & 100 & 294 \\
\hline
\end{tabular}

Table 5 illustrated that the majority of vegetable and fruit consumers in both Selangor and Johor frequently purchase goods with Halal label, followed by products with MyGap label. And it equally corresponded with the importance they placed on these labeling names. Here, the word "Halal label" indicates that the products are guaranteed for consumption and did not go against Islamic law. Perhaps, this particular finding might be influenced by religious belief since the majority of the consumers in the two states were from the Malay race, who are predominantly practicing Islamic religion.

Table 5: Descriptive outcomes of vegetable and fruit consumers on how often and importance of buying agro products based on the labeling names

\begin{tabular}{lcccccc}
\hline \multirow{2}{*}{ Label } & \multicolumn{2}{c}{$\begin{array}{c}\text { Frequency (\%) } \\
\text { Frequently }\end{array}$} & \multicolumn{2}{c}{$\begin{array}{c}\text { Importance (Frequency \%) } \\
\text { Yes }\end{array}$} & $\begin{array}{c}\text { Total } \\
\text { No }\end{array}$ & Frequency \\
\hline 1. Consumers at Selangor's wholesales market & & & \\
\hline Halal & $192(72.5)$ & $34(12.8)$ & $35(13.2)$ & $225(84.9)$ & $34(12.8)$ & 520 \\
MyGAP & $25(9.4)$ & $61(23.0)$ & $45(25.3)$ & $77(29.1)$ & $184(69.4)$ & 392 \\
Made in Malaysia & $146(55.1)$ & $57(21.5)$ & $58(21.9)$ & $178(67.2)$ & $84(31.7)$ & 523 \\
GPL & $58(21.9)$ & $62(23.4)$ & $141(53.2)$ & $107(40.4)$ & $154(58.1)$ & 522 \\
Organic Product & $56(21.1)$ & $80(30.2)$ & $125(47.2)$ & $112(42.3)$ & $146(55.1)$ & 519 \\
Total & 477 & 297 & 404 & 699 & 599 & 2476 \\
2. Consumers at Johor's wholesales market & & & \\
Halal & $189(64.3)$ & $41(13.9)$ & $46(15.6)$ & $223(75.9)$ & $41(13.9)$ & 540 \\
MyGAP & $33(11.2)$ & $106(36.1)$ & $124(42.2)$ & $71(24.1)$ & $181(61.6)$ & 515 \\
Made in Malaysia & $124(42.2)$ & $95(32.2)$ & $45(15.3)$ & $160(54.4)$ & $95(32.2)$ & 519 \\
\hline \multicolumn{7}{c}{}
\end{tabular}




\begin{tabular}{lcccccc}
\hline GPL & $42(14.3)$ & $121(41.2)$ & $100(34.0)$ & $96(32.7)$ & $158(53.7)$ & 517 \\
Organic Product & $62(21.1)$ & $109(37.1)$ & $92(31.3)$ & $101(34.4)$ & $153(52.0)$ & 517 \\
Total & 450 & 472 & 407 & 651 & 628 & 2608 \\
\hline
\end{tabular}

Table 6 demonstrated that the majority of the vegetable and fruit consumers in Selangor ranked products' quality information on packaging and environmental friendly for packaging material as the most crucial factors that could improve agricultural products. However, the consumers in Johor partly differed in their perceptions by indicating that nutrition, environmentally friendly, and high quality were the essential factors that could enhance agricultural products' packing. Therefore, it is suggested that GPL regulators should consider their perceptions of improving agricultural products' packaging qualities. This is because the findings of this study have proven that the more appealing the products' packaging is, the higher the numbers of consumers and high quantity sales would be made. Additionally, if such improvements are achieved, it might also lead to agro-based entrepreneurship sustainability.

Table 6: Descriptive outcomes of vegetable and fruit consumers on what could be improved in agricultural product packaging

\begin{tabular}{|c|c|c|c|}
\hline \multirow{2}{*}{ Packaging } & \multicolumn{2}{|c|}{ Frequency $(\%)$} & \multirow{2}{*}{$\begin{array}{c}\text { Total } \\
\text { Frequency }\end{array}$} \\
\hline & Disagree & Agree & \\
\hline \multicolumn{4}{|c|}{ 1. Consumers at Selangor's wholesales market } \\
\hline \multicolumn{4}{|c|}{ Packaging: Information } \\
\hline Origin & $30(10.8)$ & $234(14.8)$ & 264 \\
\hline Grading of product & $40(14.4)$ & $243(15.4)$ & 263 \\
\hline Tag Price & $23(8.3)$ & $240(15.2)$ & 263 \\
\hline License & $20(7.2)$ & $243(15.4)$ & 263 \\
\hline Nutrition & $31(11.2)$ & $229(14.5)$ & 260 \\
\hline Quality of product & 135 (48.6) & $393(24.8)$ & 528 \\
\hline Total & 278 & 1582 & 1841 \\
\hline \multicolumn{4}{|l|}{ Packaging: Material } \\
\hline $\begin{array}{l}\text { Environmental } \\
\text { Friendly }\end{array}$ & $44(14.3)$ & $220(26.1)$ & 264 \\
\hline Easy to open & $63(14.3)$ & $201(23.9)$ & 264 \\
\hline High Quality & $43(7.1)$ & $220(26.1)$ & 263 \\
\hline Usable & $62(64.3)$ & $201(23.9)$ & 263 \\
\hline Total & 212 & 842 & 1054 \\
\hline \multicolumn{4}{|c|}{ 2. Consumers at Johor's wholesales market } \\
\hline \multicolumn{4}{|c|}{ Packaging: Information } \\
\hline Quality of product & $159(60.0)$ & $425(21.8)$ & 584 \\
\hline Nutrition & $24(15.0)$ & $443(22.7)$ & 467 \\
\hline Tag Price & $14(5.3)$ & $278(14.2)$ & 292 \\
\hline Origin & $24(5.0)$ & $268(13.7)$ & 292 \\
\hline Grading of product & $24(5.0)$ & $268(13.7)$ & 292 \\
\hline License & $17(10.0)$ & $272(13.9)$ & 289 \\
\hline Total & 262 & 1954 & 2216 \\
\hline \multicolumn{4}{|l|}{ Packaging: Material } \\
\hline $\begin{array}{l}\text { Environmental } \\
\text { Friendly }\end{array}$ & $32(22.6)$ & $260(26.4)$ & 292 \\
\hline High Quality & $32(22.6)$ & $260(26.4)$ & 292 \\
\hline Easy to open & $60(25.8)$ & $232(23.6)$ & 292 \\
\hline Usable & $58(38.7)$ & $234(23.7)$ & 292 \\
\hline Total & 182 & 986 & 1168 \\
\hline
\end{tabular}


Table 7 presented that most of the vegetable and fruit customers in Selangor state agreed that the most GPL influences on them towards making products' preferences were expiring and manufactured dates. Therefore, it is recommended that GPL regulators should always ensure that all the agro products conveyed for sales in Selangor state are bearing expiring and manufactured dates to attract more consumers and equally retain the older ones for the sustainability of agro- based entrepreneurship. Whereas consumers in Johor state partly differed in their products' preferences by indicating that products' nutrition content and the weight were the most GPL rules that will influence their products' preferences. Consequently, it is also commended that the GPL regulators should always consider improving the products' nutrition contents and the weight of all the products delivered for sales in Johor state towards intensifying the number of sales and consumers.

Table 7: Descriptive outcomes on the impact of GPL towards influencing vegetable and fruit consumers' products' preferences

\begin{tabular}{|c|c|c|c|c|}
\hline \multirow{2}{*}{ Impact of GPL } & \multicolumn{2}{|c|}{ Disagree } & \multicolumn{2}{|c|}{ Agree } \\
\hline & Percentage $(\%)$ & Frequency & Percentage (\%) & Frequency \\
\hline \multicolumn{5}{|c|}{ 1. Consumers at Selangor's wholesales market } \\
\hline \multicolumn{5}{|c|}{ I only purchase the product, if I see: } \\
\hline Manufactured date & 4.7 & 10 & 15.4 & 282 \\
\hline Expired date & 3.3 & 7 & 15.6 & 285 \\
\hline Price tag & 7.6 & 16 & 15.1 & 276 \\
\hline Weight & 16.1 & 34 & 14.1 & 258 \\
\hline Brand & 23.2 & 49 & 13.3 & 243 \\
\hline Quality of product & 11.4 & 24 & 14.6 & 268 \\
\hline Nutrition content & 33.6 & 71 & 12.0 & 219 \\
\hline Total & 100 & 211 & 100 & 1831 \\
\hline \multicolumn{5}{|c|}{ 2. Consumers at Johor's wholesales market } \\
\hline \multicolumn{5}{|c|}{ I only purchase the product, if I see: } \\
\hline Expired date & 5.6 & 13 & 15.6 & 251 \\
\hline Price tag & 9.9 & 23 & 14.9 & 241 \\
\hline Brand & 19.4 & 45 & 13.6 & 219 \\
\hline Nutrition content & 22.4 & 52 & 13.1 & 212 \\
\hline Quality of product & 7.8 & 18 & 15.3 & 246 \\
\hline Weight & 26.3 & 61 & 12.5 & 202 \\
\hline Manufactured date & 8.6 & 20 & 15.0 & 242 \\
\hline Total & 100 & 232 & 100 & 1,613 \\
\hline
\end{tabular}

Table 8 displayed that the majority of the consumers in both Selangor and Johor strongly affirmed that they needed GPL rules on consumable products. Whereas few of them did not affair the need for GPL rules on the products. Additionally, a little percentage of the consumers in both states answered not applicable to this particular question and that also showed their ignorance on the GPL roles towards ensuring high products' qualities. Thus, the findings proposed that GPL regulators should strengthen their efforts towards certifying that all products are conforming to GPL rules. On the other hand, there is also unarguably needs to enlighten those who did not affirm the need nor understand the concept of applying GPL rules on consumable products. 
Table 8: Descriptive outcomes of vegetable and fruit consumers on the need for applying GPL Rules on agro products

\begin{tabular}{lcccc}
\hline \multirow{6}{*}{ GPL } & \multicolumn{2}{c}{ Selangor } & \multicolumn{2}{c}{ Johor } \\
\hline Yes & 88.7 & 235 & Percentage $(\boldsymbol{\%})$ & Frequency \\
No & 9.1 & 24 & 83.4 & 245 \\
N/A & 2.3 & 6 & 14.3 & 42 \\
Total & 100.0 & 265 & 2.3 & 7 \\
\hline
\end{tabular}

Table 9 demonstrated that most of the vegetable and fruit consumers in both Selangor and Johor needed the application of GPL rule for ensuring the products' qualities and gaining consumers' confidence. Consequently, the GPL regulators need to consider most these two factors towards retaining agro-products' consumers and intensifying the number of sales from the agro entrepreneurs' side.

Table 9: Descriptive outcomes of vegetable and fruit consumers on the reasons for demanding the application of GPL rules on agro products

\begin{tabular}{lcccc}
\hline Reason & \multicolumn{2}{c}{ Selangor } & \multicolumn{2}{c}{ Johor } \\
& Percentage (\%) & Frequency & Percentage (\%) & Frequency \\
\hline To ensure the quality of the & 28.2 & 200 & 32.8 & 211 \\
product & 28.4 & 201 & 27.4 & 176 \\
To gain consumers' confident & 23.4 & 166 & 22.2 & 143 \\
To ensure the safety of the & 20.0 & 142 & 17.6 & 113 \\
product & 100.0 & 709 & 100.0 & 643 \\
To control the price & & & \\
Total &
\end{tabular}

Table 10 illustrated that the most reasons that made both Selangor and Johor vegetable and fruit consumers to oppose the application of GPL rules on products, were the fears of increase on cost of living and the products' cost. Consequently, it is suggested that the GPL regulators should consider the effects of applying GPL rules on both living costs and the products' cost. Therefore, there are needs to deliberate on the negative effects on these two factors towards subsiding the cost of GPL applications on consumable products to resolve the consumers' fears and encouraging them to comply with it.

Table 10: Descriptive outcomes on the vegetable and fruit consumers' reasons for opposing the need for GPL application on agro products

\begin{tabular}{lcccc}
\hline \multirow{2}{*}{ Reason } & \multicolumn{2}{c}{ Selangor } & \multicolumn{2}{c}{ Johor } \\
& Percentage (\%) & Frequency & Percentage (\%) & Frequency \\
\hline Increase cost of the product & 35.0 & 7 & 61.2 & 41 \\
Not give any beneficial to & 0.0 & 0 & 11.9 & 8 \\
consumers & 55.0 & 11 & 22.4 & 15 \\
Increase cost of living & 10.0 & 2 & 4.5 & 3 \\
Others & 100 & 20 & 100 & 67 \\
Total & \multicolumn{4}{c}{} \\
\hline
\end{tabular}

Table 11 showed that most of the vegetable and fruit consumers in both Selangor and Johor were not aware of GPL. Therefore, there was low awareness on the impact of GPL to the consumers. Consequently, consumers in both states, need enlightenment and awareness campaigns towards educating them on the impact of applying GPL rules on consumable products for ensuring high quality and safety consumptions. This could be further done via various new mediums' platforms and traditional mediums such as television, radio, etc. 
Table 11: Descriptive outcomes on vegetable and fruit consumers' GPL Awareness

\begin{tabular}{lcccc} 
GPL & \multicolumn{2}{c}{ Selangor } & \multicolumn{1}{c}{ Johor } \\
& Percentage $(\%)$ & Frequency & Percentage $(\%)$ & Frequency \\
\hline Yes & 32.5 & 86 & 39.1 & 115 \\
No & 67.2 & 178 & 58.2 & 171 \\
N/A & 0.4 & 1 & 2.7 & 8 \\
Total & 100.00 & 265 & 100 & 294 \\
\hline
\end{tabular}

\subsection{Cost and benefit analysis (On Product)}

Table 12 indicated that the vegetable and fruit consumers in both Selangor and Johor stated that GPL's current rules were most affecting their household expenditures and the products' cost at large. Hence, there are pressing needs for GPL regulators to readjust the current effects of GPL rules on the household expenditures and the products' prices by subsiding the cost of the current GPL rules on consumable products towards retaining and attracting more consumers. Additionally, GPL regulators should regulate the current GPL affects for the aim of sustaining agro-based products and agro entrepreneurship in Malaysia.

Table 12: Descriptive outcomes on the effect of current GPL rules on agro products

\begin{tabular}{lcccccccc}
\hline \multirow{2}{*}{ Current rules } & \multicolumn{2}{c}{ No changes } & \multicolumn{2}{c}{ Reduce } & \multicolumn{2}{c}{ High } & \multicolumn{2}{c}{ Very high } \\
\% & $\mathbf{f}$ & $\mathbf{\%}$ & $\mathbf{f}$ & $\mathbf{\%}$ & $\mathbf{f}$ & $\mathbf{\%}$ & $\mathbf{f}$ \\
\hline 1. Consumers at Selangor's & wholesales & market & & & & & & \\
Quality of product & 10.3 & 69 & 5.7 & 16 & 10.8 & 129 & 11.4 & 50 \\
Grading of product & 9.7 & 65 & 6 & 17 & 11.5 & 138 & 10 & 44 \\
Product labeling & 8.8 & 59 & 8.1 & 23 & 11.6 & 139 & 9.8 & 43 \\
Price of product & 6.7 & 45 & 7.1 & 20 & 11.7 & 140 & 13.4 & 59 \\
Cleanest of premises & 11.1 & 74 & 14.5 & 41 & 8.3 & 99 & 11.4 & 50 \\
Product safety & 10.8 & 72 & 9.5 & 27 & 9.2 & 110 & 12.5 & 55 \\
Waste management system & 11.9 & 80 & 16.6 & 47 & 8.1 & 97 & 8.9 & 39 \\
Air quality & 12.1 & 81 & 16.9 & 48 & 8.2 & 98 & 8.4 & 37 \\
Motivation to do business & 10.3 & 69 & 10.9 & 31 & 9.4 & 113 & 0.2 & 1 \\
Household expenditure rate & 8.1 & 54 & 4.6 & 13 & 11.3 & 136 & 13.9 & 61 \\
Total & 100 & 668 & 100 & 283 & 100 & 1199 & 100 & 439 \\
2. Consumers at Johor's wholesales market & 9.2 & 43 & 11.3 & 27 & 9.5 & 135 & 11.2 & 85 \\
Quality of product & 8.8 & 41 & 9.6 & 23 & 10.9 & 156 & 9.2 & 70 \\
Grading of product & 8.8 & 41 & 6.7 & 16 & 10.9 & 157 & 10.1 & 77 \\
Product labeling & 6.2 & 29 & 8.3 & 20 & 10.3 & 147 & 11.9 & 91 \\
Price of product & 11.9 & 56 & 11.7 & 28 & 9.7 & 139 & 8.8 & 67 \\
Cleanest of premises & 11.4 & 53 & 7.9 & 19 & 9.7 & 139 & 10.1 & 77 \\
Product safety & 12.2 & 57 & 19.6 & 47 & 8.6 & 123 & 8.4 & 64 \\
Waste management system & 12.2 & 57 & 12.5 & 30 & 9.7 & 139 & 8.5 & 65 \\
Air quality & 10.5 & 49 & 8.8 & 21 & 10.6 & 152 & 8.7 & 66 \\
Motivation to do business & 8.8 & 41 & 3.8 & 9 & 9.9 & 141 & 13 & 99 \\
Household expenditure rate & 100 & 467 & 100 & 240 & 100 & 1428 & 100 & 761 \\
Total & & & & & & & &
\end{tabular}




\section{CONCLUSION}

In conclusion, the purpose of the study which, focused on contributing to the emerging agroentrepreneurship empirical literature from the Malaysian regulatory impact analysis context, found that the majority of the consumers had little knowledge about grading, packaging, and labelling (GPL). Consumers were also not aware of the concept of applying GPL rules on consumable goods. The study equally established that over two-thirds of the customers always check the label on the products before they purchase them. It further demonstrated that the majority of the consumers were concerned with the Halal label when purchasing products. However, the consumers in Selangor highlighted the importance of products' quality information on the packaging and environmental friendly for packaging materials. Whilst, the consumers in Johor put nutrition contents and environmental friendly as well as high quality as priorities towards improving products' packaging. Regarding the major concern on how to improve GPL impacts on consumable goods, the consumers ranked adding expiring and manufactured dates on agro-products as their major concerns. The consumers further demonstrated that they needed GPL rules' applications for ensuring the products' qualities and the products' safety consumptions. Additionally, consumers from both states pointed increase in household expenditures and products' prices as most factors affecting their compliance with the current application of GPL rules. Therefore, the GPL regulators need to subside the GPL current application cost in order not to dissuade consumers from complying with the policy.

The findings further show that despite some negative effects, the implementation of regulatory analysis may have on the consumers and agro entrepreneurs' expenditures, the good news is that it would also maximize their satisfaction by ensuring the qualities and safety consumptions of the products they purchase. Consequently, our findings supported Migliore et al. (2017) and Corsi and Mazzocchi (2019) that effective management of agro products will improve the qualities and ensure the products' safety consumptions. Thus, this study recommends the full application of RIA in Malaysia and also contributes empirical evidence to the emerging agro-entrepreneurship literature through exploring the regulatory impact analysis from the Malaysian context. It further provides knowledge on the impact of economics towards agricultural sustainability by demonstrating that the judicious application of economics, has a huge role in increasing the economic growth in Malaysia through agricultural products. It finally proved that the Agricultural profession plays a vital role in ensuring the nations' food security and also in creating job opportunities towards meeting up with the Malaysian agenda of becoming among developed countries by the year 2030 .

Funding: This study received no specific financial support.

Competing Interests: The author declares that he has no competing interests.

Contributors/Acknowledgement: This work was supported morally and financially by the Universiti

Putra Malaysia and the Ministry of Higher Education, Malaysia.

Views and opinions expressed in this study are the views and opinions of the authors, Asian Journal of

Agriculture and Rural Development shall not be responsible or answerable for any loss, damage or liability,

etc. caused in relation to/arising out of the use of the content.

\section{References}

Abdullah, A., Yaacob, M. R., Ismail, M. B., Zakaria, M. N., Abdullah, Z., \& Mohd Radyi, S. A. (2017). Corporate engagement with the community: Building relationships through CSR. Journal of Engineering and Applied Sciences, 12(6), 1538-1542.

Abdullah, Z., \& Abu Seman, R. A. (2018). Constructing a unique online corporate identity of Korean companies. Conference Proceeding of International Conference on Business, Economics \& Finance (ICBEF), 10-12. April 2018 at Penang.

Abdullah, Z. (2009). Beyond corporate image: Projecting international reputation management as a new theoretical approach in a transitional country. International Journal of Economics and Management, 3(1), 170-183.

Abdullah, Z. (2010). Cultural diversity management in Malaysia: A perspective of communication management. In M. Özbilgin \& J. Syed (Eds.), Managing cultural diversity in Asia (pp. 14- 
38). Gheltenham: Edward Elgar Publishing Limited.

Abid, M., Schneider, U. A., \& Scheffran, J. (2016). Adaptation to climate change and its impacts on food productivity and crop income: Perspectives of farmers in rural Pakistan. Journal of Rural Studies, 47, 254-266. doi.org/10.1016/j.jrurstud.2016.08.005.

Akhmetova, S. O., Baibolova, L. K., \& Serikkyzy, M. S. (2019). Integrated quality management system for food production: a case of dairy products' enterprise. Entrepreneurship and Sustainability Issues, 6(4), 1807-1822.

Akhmetova, S. O., Fuschi, D. L., \& Vasiliūnaite, R. (2017). Towards Food Safety: Quality Management Peculiarities. Journal of Security \& Sustainability Issues, 6(3), 513-522. doi.org/10.9770/jssi.2017.6.3(15).

Bonroy, O., \& Constantatos, C. (2015). On the economics of labels: How their introduction affects the functioning of markets and the welfare of all participants. American Journal of Agricultural Economics, 97(1), 239-259. doi.org/10.1093/ajae/aau088.

Bowen, F., Tang, S., \& Panagiotopoulos, P. (2020). A classification of information-based environmental regulation: Voluntariness, compliance and beyond. Science of The Total Environment, 712, 135-571. doi.org/10.1016/j.scitotenv.2019.135571.

Capone, R., El Bilali, H., \& Bottalico, F. (2016). Assessing the sustainability of typical agro-food products: insights from Apulia Region, Italy. New Medit, 15(1), 28-35.

Carroll, S. L., Embuldeniya, G., Abelson, J., McGillion, M., Berkesse, A., \& Healey, J. S. (2017). Questioning patient engagement: research scientists' perceptions of the challenges of patient engagement in a cardiovascular research network. Patient preference and adherence, 11, 1573-1583.

Cooper, H., Hedges, L. V., \& Valentine, J. C. (Eds.). (2019). The handbook of research synthesis and meta-analysis. Russell Sage Foundation.

Corsi, S., \& Mazzocchi, C. (2019). Alternative Food Networks (AFNs): determinants for Consumer and farmer participation in Lombardy, Italy. Agricultural Economics, 65(6), 259-269.

Ekpe, I., Razak, R. C., Ismail, M., \& Abdullah, Z. (2015). Entrepreneurial skill acquisition and youth's self-employment in Malaysia: How far? Mediterranean Journal of Social Sciences, 6(4), 150-154.

Ekpe, I., Razak, R. C., Ismail, M., \& Abdullah, Z. (2016). Entrepreneurial skill acquisition, psychosocial factors and youth's self-employment in Malaysia. Journal of Entrepreneurship Education, 19(2), 78-88.

Glavan, M., Železnikar, Š., Velthof, G., Boekhold, S., Langaas, S., \& Pintar, M. (2019). How to enhance the role of science in European Union policy making and implementation: The case of agricultural impacts on drinking water quality. Water, 11(3), 1-22. doi.org/10.3390/w11030492 .

Haider, A. Bashir, A., \& Husnain, M. I. (2020). Impact of agricultural land use and economic growth on nitrous oxide emissions: Evidence from developed and developing countries. Science of The Total Environment, 74, 140-421. doi.org/10.1016/j.scitotenv.2020.140421.

Jensen, N., \& Barrett, C. (2017). Agricultural index insurance for development. Applied Economic Perspectives and Policy, 39(2), 199-219.

Kirkpatrick, C., \& Lee, N. (2002). Further development of the methodology for a sustainability impact assessment of proposed WTO Negotiations. Final Report to the European Commission, IDPM, University of Manchester, Manchester. (See www.man.ac.uk/idpm/sia).

Kirkpatrick, C., Parker, D., \& Zhang, Y. (2003). Regulatory impact assessment in developing and transition economies: A survey of current practice and recommendations for further development. In Regulatory Impact Assessment Conference, Manchester (pp. 26-27).

Kirkpatrick, C., \& Parker, D. (2003). Regulatory impact assessment: developing its potential for use in developing countries. Center on Regulation and Competition.

Kowalczyk, C., Nowak, M., \& Źróbek, S. (2019). The concept of studying the impact of legal changes on the agricultural real estate market. Land Use Policy, 86, 229-237.

Migliore, G., Borsellino, V., Schifani, G., Di Gesaro, M., \& Schimmenti, E. (2017). Good, safe and fair: Quality perception and consumer demand of locally produced beef in Southern Italy. New Medit, 16(3), 39-46. 
Neto, R. M., Nocko, H. R., \& Ostrensky, A. (2015). Environmental characterization and impacts of fish farming in the cascade reservoirs of the Paranapanema River, Brazil. Aquaculture Environment Interactions, 6(3), 255-272.

Nie, W., Li, T., \& Zhu, L. (2020). Market demand and government regulation for quality grading system of agricultural products in China. Journal of Retailing and Consumer Services, 56, $102-134$.

OECD, (2020). Regulatory impact analysis: Best practices in OECD Countries, OECD, Paris

Oliveira, H., \& Penha, L. G. (2020). Permaculture in portugal: social-ecological inventory of a reruralizing grassroots movement. European Countryside, 12(1), 30-52.

Paraskevopoulou, C., Theodoridis, A., Johnson, M., Ragkos, A., Arguile, L., Smith, L., \& Arsenos, G. (2020). Sustainability assessment of goat and sheep farms: a comparison between european countries. Sustainability, 12(8), 1-23. doi.org/10.3390/su12083099.

Parker, D. (2006). Regulation and market liberalization in developing countries: a preliminary literature review and commentary. Centre for Research on Regulation and Competition Working Paper, University of Manchester (mimeo).

Pölling, B., Prados, M. J., Torquati, B. M., Giacchè, G., Recasens, X., Paffarini, C., \& Lorleberg, W. (2017). Business models in urban farming: A comparative analysis of case studies from Spain, Italy and Germany. Moravian Geographical Reports, 25(3), 166-180. doi.org/10.1515/mgr-2017-0015.

Quintas, S. C., Castro, A. J., Castro, H., \& García-Llorente, M. (2016). Impacts of land use change on ecosystem services and implications for human well-being in Spanish drylands. Land Use Policy, 54, 534-548.

Schneider, U. A., Havlík, P., Schmid, E., Valin, H., Mosnier, A., Obersteiner, M., Böttcher, H. Skalský, R., Balkovič, J., Sauer, T., \& Fritz, S. (2011). Impacts of population growth, economic development, and technical change on global food production and consumption. Agricultural Systems, 104(2), 204-215. doi.org/10.1016/j.agsy.2010.11.003.

Vignola, R., Harvey, C. A., Bautista-Solis, P., Avelino, J., Rapidel, B., Donatti, C., \& Martinez, R. (2015). Ecosystem-based adaptation for smallholder farmers: Definitions, opportunities and constraints. Agriculture, Ecosystems \& Environment, 211, 126-132. doi.org/10.1016/j.agee.2015.05.013.

Williams, T. O. (2015). Reconciling food and water security objectives of MENA and sub-Saharan Africa: is there a role for large-scale agricultural investments?. Food Security, 7(6), 11991209. doi.org/10.1007/s12571-015-0508-z.

$\mathrm{Yu}, \mathrm{V}$. K. (2017). Introducing sectoral models into regional management: An assessment of regulatory impacts on the economy. Baltic Region, 9(4), 74-86. doi.org/10.5922/2079-85552017-4-5

Zhang, W., \& Tidgren, K. (2018). The current farm downturn vs the 1920s and 1980s farm crises: An economic and regulatory comparison. Agricultural Finance Review, 78(4), 396-411. doi.org/10.1108/afr-08-2017-0075. 